\title{
Становлення русофільського та народовецького національно-культурних рухів у Закарпатті
}

\begin{abstract}
Strjapko Ivan, Stanovlennja rusofils'koho ta narodovec'koho nacionalno-kulturnych ruchiv u Zakarpatti (Development of Russophile and Narodovetsky Movements in Transcarpathia). „Poznańskie Studia Slawistyczne” 8. Poznań 2015. Publishing House of the Poznań Society for the Advancement of the Arts and Sciences, pp. 183-198. ISSN 2084-3011.

The article researches a development of the national-cultural movements. The attention is paid to the development of Russophiles and its organizational center „Organization of Saint Vasyl the Great". Author describes the discussion among Transcarpathian intellectuals regarding the use of Russian language. The refusal of Russophilism by the part of intellectuals led to the development of Narodovetskyy movement. The author explains this process as a stage before development of Ukrainophile movement.
\end{abstract}

KEYwORDs: Russophilism; Transcarpathia; cultural; education; history

Проблема формування в Закарпатті національно-культурних рухів та їх діяльність є малодосліджена, а тому дуже дискусійна та гостра. Більшість дослідників зосереджуються на дослідженнях історії церкви, оскільки є потужна джерельна база, або на дослідженнях чехословацького періоду історії Закарпаття, який охоплює 1919-1939 рр. Подекуди, увагу вчених привертають особливості економічного розвитку. Відтак, проблеми національно-культурного розвитку малодосліджені. 3 одного боку, це пояснюється доволі слабкою джерельною базою. 3 іншого, відсутністю методологічної бази. До прикладу, тривалий час частина діячів культури XIX ст. розглядалася як „будителі”. Таким терміном позначалися ті діячі, які вважалися засновниками національно-культурного руху, початківцями просвітництва. Щоправда, вони були представниками русофільського напрямку, а отже сучасна українська історична наука не розглядає їх як частину українського 
національно-культурного руху. Цим можна пояснити слабке зацікавлення сучасних дослідників зазначеною проблематикою. Хоч, на нашу думку, розкол у суспільстві на українофілів та русофілів протягом чехословацького періоду має витоки саме у другій половині XIX ст.

Аналізуючи „проблему історіографіі” дослідження національнокультурних рухів Закарпаття зазначимо, що з даної проблеми існує декілька узагальнюючих праць та дослідження, які стосуються вужчої проблематики. Серед узагальнюючих студій відмітимо праці П.Р. Магочія (1994) Д. Данилюка (1997), П. Ференца (2005), І. Стряпка (2012).

Проблема розвитку літератури, а отже частково й літературної мови, найбільш повно відображена у праці С. Недзъльського (1932). Варто зазначити, що автор був прихильником русофільства, тому його позиція $є$ ангажована, відтак повинна сприйматися дослідниками критично. Аналогічним прикладом, але з боку українофілів, можна вважати працю В. Бірчака (1937).

Починаючи „виклад матеріалу” нашого дослідження - визначимо, що під терміном „національно-культурний рух” ми розуміємо: просвітницьку, виховну, агітаційну, видавничу діяльність, спрямовану на формування у населення певного виду ідентичності. Така діяльність була пов'язана з використанням літературної мови, язичія, української, російської мов, а також поширенні української чи російської культури.

Народовецький рух - ми трактуємо як один з етапів становлення українофільського руху. В українських дослідників цей термін використовується як синонім терміну українофільський. Ми ж розуміємо його як діяльність частини закарпатської інтелігенції, яка відмовилася від русофільства, але ще не перейшла на позиції українофільства. Проте не заперечувала належності жителів Закарпаття до української нації.

Як методологічну основу нашого дослідження використовуємо концепцію Мирослава Гроха. Згідно неї, виділяються три періоди:

1. „,академічний”, дослідницький, коли певна національна (етнічна) спільнота виокремлюється етнографами, мовознавцями, фольклористами тощо як об'єкт суто наукового інтересу;

2. просвітницько-патріотичний, коли національна свідомість як свідомість своєї окремішності вноситься прошарком інтелігенції 
- „піонерів національної ідеї” - вглиб етнічного масиву (через постання національної школи, преси і т.д.);

3. політичний, тобто вже безпосереднє оформлення політичних організацій, які й артикулюють вимоги державності. Досліджуваний нами період можна розглядати як перехід від першого до другого періоду.

Появу русофільського руху в історичному Закарпатті як структурованого та організаційно оформленого ми фіксуємо у 1864 р. Саме тоді було засновано „Общество святого Василія Великого”. Дехто з дослідників засновниками русофільського національно-культурного руху вважає О. Духновича та А. Добрянського. Проте жоден з них не може повною мірою вважатися таким. Перший був культурним діячем, проте не мав чітко окреслених поглядів. Другий, попри свої симпатії до русофільства, був послідовним прихильником Австрії. Саме тому появу русофільства як організованого руху слід виводити від „Общества святого Василія Великого”. Учасники товариства, як й програмні документи, стверджують, що ініціаторами його створення виступили греко-католицькі єпископи - Мукачівський Василь Попович та Пряшівський Й. Гаганець (Сильвай 1957: 127). Проте аналіз діяльності товариства свідчить, що справжнім ініціатором його створення був I. Раковський.

Метою товариства проголошувалося ,поширення корисних книг і розвивати угро-русскую літературу" (Общество СВ. Василія Великого 1866: 69). У коло його дій також входило поширення корисних відомостей через видання книг і різних іконописних зображень (Общество СВ. Василія Великого 1866: 69). Статут товариства був затверджений угорською королівською намісницькою владою ще 15 грудня 1864 р., але смерть єпископа В. Поповича перешкодила проведенню установчих зборів. Вони відбулися 11 вересня (1 жовтня) 1866 р. На цих зборах було обрано керівництво „Общества святого Василія Великого” та визначено основні пріоритети діяльності. Першим головою став А. Добрянський, другим обрали І. Раковського. Оскільки А. Добрянський практично не брав участі в управлінні „Обществом святого Василія Великого" - він був номінальним головою. Реальне керівництво зосередилося у руках I. Раковського. Тут варто зазначити, що серед інтелігенції історичного Закарпаття, а це були переважно 
греко-католицькі священики, А. Добрянський користувався неабияким авторитетом. Тому обрання його головою товариства варто розцінювати як намагання спертися на його авторитет.

Загалом новостворене товариство з часу свого виникнення здійснювало не масову культурно-просвітницьку діяльність серед населення, а роботу серед інтелігенції. Таку позицію можна пояснити, по-перше, асиміляцією, яку зазнала світська інтелігенція; по-друге, невизначеністю у середовищі греко-католицького кліру стосовно національної ідентичності; по-третє, намаганням накинути їм русофільство як альтернативу національно-культурного руху; по-четверте, це означало не готовність інтелігенції до ведення культурно-просвітницької роботи серед населення; по-п’яте, така діяльність характеризує iii апатичність та замкнутість. В той час як словацька та чеська інтелігенція вела культурно-просвітницьку роботу серед населення, закарпатська зосередилася на творенні культурного конструкту для вузької групи осіб.

Все ж варто зазначити, що створення культурного товариства викликало значний інтерес у середовищі закарпатської інтелігенції. Його членами стали 348 чоловік (Протоколь Перваго общаго собранія Общества. св. Василія В. 1867: 72), за даними А.Волошина 500 чоловік (ДАЗО 1937: 3). Це була досить значна цифра, враховуючи замкнутість та пасивність греко-католицького кліру. Невдовзі постало питання про створення періодичного видання, яке мало б слугувати друкованим органом „Общества святого Василія Великого” (Протоколь перваго засъданія комитета Общества св. Василія В. 1866: 77). Вирішено було, що таким друкованим органом стане газета, яка повинна була займатися виключно церковними, педагогічними та літературними проблемами, уникаючи політики (Протоколъ третяго засьданія комитета О. св. Василія В. 1867: 81). Газету планувалося назвати „Свђт” (пізніше „Новий Свът” і „Карпат”) і випускати як тижневик (щосуботи), а ії редактором було призначено Ю. Ігнаткова. Редактор і „Общество святого Василія Великого” укладали окремий договір, який регулював їх відносини (ДАЗО 1937: 3).

Іва́н Раковський виходив з того, що русини (корінне слов'янське населення Підкарпатської Русі) - „маленькая подкарпатская ветвь русского народа" (Протоколь третяго засъданія комитета О. св. 
Василія B. 1867: 81), а отже завданням товариства вбачав поширення російської мови та російської культури. Слід відмітити, що російською мовою серед інтелігенції мало хто володів, а отже й російська культура для закарпатської інтелігенції була невідомою. Показовими 3 цього приводу є слова русофіла І. Сільвая, який зазначав, що:

В начале 60-х годов моё ведение в русском языке было ещё недостаточно. Оно ограничивалось простонародным говором (...). Если я желал что-нибудь изложить по-русски, то прежде должен был составить по-мадьярски и то самое переводить на русский язык; но и тот перевод выходил крайне неуклюжим, тяжёлым и исполненным мадьяризмами (Сильвай 1957: 41).

Спроби русофілів самостійно вивчити російську мову призвели до вироблення суміші церковнослов'янської та російської мов із додаванням місцевих діалектів, яку русофіли гордо називали „русским языком”, а їх критики іменували „язичієм”. Зазначимо, що уряд Російської імперії у 60-70-х рр. XIX ст. не проводив цілеспрямованої політики підтримки русофільства, хоч при нагоді всіляко цьому сприяв. Тому серйозної підтримки русофіли не отримували.

Серед інтелігенції погляди I. Раковського однак не були загальноприйнятими. Частина членів „Общества святого Василія Великого” виказували невдоволення русофільством. Тому позиція І. Раковського $з$ мовного питання викликала гостру дискусію серед інтелігенції. Проблема зводилася до того, яку мову використовувати - російську чи мову наближену до народної. Зрештою дискусія настільки загострилася, що А. Добрянський змушений був закликати до компромісу - щоб кожен писав як уміє (Воскресенский 1958а: 16).

Проте I. Раковський наполягав на використанні російської мови, вважаючи що без неї просвітлення народу - пустий звук (Воскресенский 1958b: 130). Зрештою мовні суперечки призвели до того, що кількість членів товариства й підписувачів газети „Свът” різко скоротилася. Один із дописувачів під псевдонімом Верховинец (Тіхий 1996: 81) виступив $з$ критикою мовної політики „Общества святого Василія Великого” і газети „Свђт”, зокрема. Указавши, що причиною падіння популярності газети „Свђт” в очах інтелігенції була їі мова, оскільки вона друкувалася малозрозумілою або взагалі не зрозумілою мовою, звідси громадськість утратила інтерес до неї. 
Другим каменем спотикання стало висловлювання I. Раковського про те, що „Общество святого Василія Великого” завжди враховує інтереси православної віри та „русской народности” (Гаджега 1925: 174; Недзъльскій 1932: 181). Це призвело до конфлікту з єпископом мукачівським С. Панковичем та угорською владою. Греко-католицька церква не могла дозволити собі підтримувати товариство яке відверто агітувало за православ'я. Тому між І. Раковським та єпископом мукачівським розгорівся конфлікт. До того ж єпископ був противником російської мови й вимагав творення власної літературної мови - угроруського язика (Коломиец 1962: 251).

Єпископ домагався усунення I. Раковського з посади голови. Крім того, він написав скаргу уряду, в якій називав діяльність „Общества святого Василія Великого” небезпечною, указував, що товариство нехтувало Статутом і проводило політичні збори (Кобаль 2001a: 16-17). Відтак на шостих загальних зборах у 1871 р. І. Раковського й А. Добрянського було усунуто, а на їх місце обрано О. Негребецького та Г. Маркоша. 3 їх обранням активність „Общества святого Василія Великого" знижується: крім проведення щорічних загальних зборів і видання місяцьословів воно більше ніяк не виказувало свою діяльність i, за словами А. Волошина, проявляло „не жизнь, но вегетацію” (Волошин 2001: 55).

Поступово русофіли почали відходити від „Общества святого Василія Великого” і гуртуватися довкола газети „Листок”, яку редагував Є. Фенцик (Владімір). Сама ж діяльність товариства поступово занепадала. Професор О. Бонкало вважав, що саме русофільство в літературі та суспільному житті призвело до деградації й неписьменності населення (до 86\% неписьменних станом на 1900 р.) та мадяризації інтелігенції (ДАЗО 1937: 3).

Що стосується формування українофільського національнокультурного руху, то він постає значно пізніше. Попри намагання частини закарпатських дослідників довести, що він передував русофільству (Данилюк 1997; Ференц 2005), на нашу думку, організаційно (він) той оформився лише у 1920 р., коли було створено товариство „Просвіта”. Ми вважаємо, що перший етап - народовецький, починається у кінці XIX ст. $з$ часом він перетворився в українофільський рух. 
Початок формування народовецького руху, який став основою українофільського, слід віднести до 1892 р. Тоді відбулася спроба відновити діяльність „Общества святого Василія Великого”. Ініціаторами були єпископом Мукачівський Ю. Фірцак та Пряшівський І. Валій. 29 серпня 1895 р. відбулися загальні збори, було обрано нового голову - I. Яковича, а покровителями стали єпископи Мукачівський Ю. Фірцак та Пряшівський I. Валій (Кондратович 1927: 46). На цих зборах було вирішено видавати газету, яка почала виходити з 1897 р. Її редакторами були Ю. Чучка, потім - В. Гаджега, а з 1903 р. - А. Волошин, дещо пізніше - В. Желтвай. Саме поява у „Обществі святого Василія Великого” А. Волошина, В. Гаджеги, В. Желтвая - людей, які пізніше стали засновниками товариства „Просвіта”, дає підстави говорити про формування народовецького руху.

Одночасно вирішили придбати для потреб товариства друкарню, що й було зроблено в 1899 р. за 6000 корон, причому частина суми була позичена з єпархіальної каси (Волошин 1995: 39). Відродження діяльності товариства викликало нападки з боку угорської преси та проугорськи налаштованих представників місцевої інтелігенції. Угорський уряд погодився затвердити статути „Общества святого Василія Великого" за умов тотального контролю за діяльністю товариства (Кондратович 1927: 37).

Такі умови не були прийнятними для „Общества святого Василія Великого", тому почали обговорюватися інші можливості культурнопросвітницької роботи. Зрештою за ініціативою А. Волошина було вирішено створити акційне видавниче товариство, оскільки торговельний закон забезпечував свободу діяльності акційних структур (Волошин 1995: 41). Цьому органові планувалося передати все майно й усі борги „Общества святого Василія Великого”. У 1902 р. відбулися ліквідаційні збори товариства й було оголошено про створення акційного товариства „Уніо”, до якого ввійшли всі діячі щойно розпущеного „Общества святого Василія Великого”.

Таким чином, закарпатська інтелігенція припинила вести будь-яку просвітницьку діяльність. Культурно-просвітницьких товариств, таких як „Просвіта”, Наукове товариство імені Т. Шевченка (НТШ), що відігравали значну роль у процесі національного відродження в Галичині, тут не було. Діячі з Наддніпрянської України тривалий час теж не 
звертали увагу на, як іiї тоді називали, Угорську Русь. Винятком тут став М. Драгоманов, котрий у 1876 р. побував у Мукачеві, Ужгороді й зустрічався $з$ представниками закарпатської інтелігенції. Він був вражений культурною відсталістю і станом національної свідомості населення. Ще більше його здивувала позиція інтелігенції, адже та майже нічого не робила для покращення ситуації. Тому, щоб хоч якось зарадити тій справі, М. Драгоманов склав спеціальну відозву, де просив збирати й надсилати йому фольклорні матеріали. На його заклик першим відгукнувся А. Кралицький (Голенда 1984: 8). Однак цим М. Драгоманов не обмежився - він помістив статтю у французькому місячнику „Le Travalleur", вказуючи на злиденне становище русько-українського народу в Угорщині (Мыцюк 1930: 154). Невдовзі й у Львові було опубліковано ряд його статей, у яких змальовувалося становище в „Угорській Русі” та містився заклик до галицької інтелігенції „подати руку допомоги своїм братам з того боку кордону" (Мушинка 1987: 29).

На заклик М. Драгоманова відгукнулися галицькі діячі, зокрема тут слід відзначити I. Франка та В. Гнатюка. I. Франко на підставі аналізу галицьких і закарпатських рукописних збірок доводить єдність їх мови та спільність тематики (Франко 1900: 38). Таким чином, його варто вважати популяризатором історичного Закарпаття серед галицьких діячів. У 1896 р. $з$ його ініціативи галицька інтелігенція склала маніфест „І ми в Європі. Протест галицьких русинів против мадярського тисячоліття” (Кобаль 2001в: 23), де наголошувалося на приналежності закарпатських русинів до українського народу й висловлювався протест проти політики мадяризації, мета якої - знищити будь-які сліди Руси в Угорщині. Цей протест підписали I. Франко та ще 45 галицьких діячів.

Володи́мир Гнатюк здійснив шість етнографічних експедицій землями Австро-Угорщини, першу з них в Закарпаття. Мету своєї експедиції він визначив так:

Собрать возможно наибольшее количество материалов, напечатать их и тем самым доказать, что Угорская Русь ещё не совсем помадярилась, что там живут русины, что она не утратила характеристических черт украинско-русского народа (Хланта 1993: 321).

Результатом його експедицій стало видання „Етнографічні матеріяли з Угорської Русі” - праці, яка принесла авторові визнання. Місцева 
інтелігенція схвально відгукнулася про його дослідження. Крім того, він написав чимало статей про історичне Закарпаття, посилюючи інтерес української інтелігенції до неї. Невдовзі й інші українські дослідники зацікавилися землями за Карпатами. Так, у 1900 р. та 1912 р. фольклорист Ф. Колесса записував народні пісні та мелодії до них на Великоберезнянщині та Пряшівщині (Милославскій 1936: 127). Український дослідник I. Верхратський вивчав говірки, а наслідком його діяльності стала монографія „Знадоби для пізнання угорсько-руських говорів”. Професор львівського університету С. Томашівський видав в 1910 р. „Етнографічну карту Угорської Русі”.

Важливим наслідком зацікавлення українською інтелігенцією Закарпаттям стало не лише вивчення історії, збирання етнографічних і фольклорних матеріалів, а й залучення закарпатської інтелігенції до загальноукраїнської культури, стимулювання в них інтересу до збирання народної творчості та співпраці з культурними та науковими установами, зокрема НТШ. Налагодження співпраці, а також контактів загалом, сприяло формуванню серед закарпатської інтелігенції розуміння необхідності вести культурно-просвітницьку роботу серед населення. Контакти з Галичиною ставали в нагоді, позаяк звідти інтелігенція отримувала не лише свіжі ідеї, але й методи та форми роботи серед селян, які були успішно апробовані галичанами. Ми маємо достатню кількість фактів, що свідчать про співпрацю між закарпатською та галицькою інтелігенцією, а ще про намагання організувати культурно-просвітницьку працю серед населення (Стряпко 2012: 70).

Варто відмітити, що не вся закарпатська інтелігенція вдалася до співпраці. Представники старшого покоління, які стояли здебільшого на русофільських або проугорських позиціях, відмовилися від контактів з НТШ. Зокрема, відомий русофільський діяч С. Сабов відповів так: „Язык того общества намъ совсем чужій и непонятный есть, мы его не разумеем. У нас бы высмеяли человека, еслы бы вашимъ испольщенымъ и испорченым жаргоном пробовалъ говориты либо писати" (Недзьльскій 1932: 256-257).

Проте молодше покоління інтелігенції - Ю. Жаткович, Г. Стрипський, Л. Дем'ян та інші - досить активно співпрацювало 3 українською інтелігенцією. 3 часом вони сприяли перетворенню народовецького руху на українофільський. Найбільш помітною 
у співпраці з галичанами була роль Ю. Жатковича та Г. Стрипського. Саме знайомство з Ю. Жатковичем, на думку о. Анастасія (В. Пекаря), заохотило В. Гнатюка до будительської праці серед закарпатських українців, а також його намагання познайомити галицьких діячів із Закарпаттям (Пекар 1991: 64).

Саме в них можна чітко зафіксувати українську ідентичність. Так, у листі до В. Гнатюка від 10 грудня 1896 р. Ю. Жаткович писав: „Я по убіжденію держу себе сыном малоруського народа, того народа, который совсім так отдільний $є$ от велико-руського, як, напримір, от польського или болгарського" (Мазурок 2001: 53).

Як бачимо, Ю. Жаткович не лише вважає себе українцем, але й чітко відмежовує українців від росіян, на відміну від І. Сільвая, I. Раковського, Ю. Ставровського-Попрадова з їх ідеями „общерусскости". Попри це мова його листа дуже далека від норм української літературної мови.

Крім Ю. Жатковича варто згадати й Г. Стрипського. Його погляди були подібними до поглядів Ю. Жатковича, що дало можливість чеському досліднику Ф. Тіхому вважати його справжнім українським письменником (Тіхий 1996: 127). Гіядор Стрипський також займався перекладами та популяризацією української літератури. Крім того, саме він радикально змінив правопис: наприклад замість „оิ” вживаючи „і”, лише в деяких випадках залишив „оิ”. Такий правопис був перейнятий газетою „Наука”.

На початку XX ст. важливу роль у розвитку українофільського руху відіграли місяцослови та газета „Наука”, редактором якої був А. Волошин. Сильно змінилася й мова видань у порівнянні з кінцем XIX ст. До прикладу, газета „Наука” друкувалася „язичієм”, але спостерігалася тенденція наближення її мови до народної. На відміну від попередніх видань газета гостро виступала проти русофільства. Частина сучасних дослідників вважає, що редакція дотримувалась автохтонських позицій (Лісовий 1970: 35), ми ж схиляємося до думки, що вона стояла на народовецьких позиціях.

Аналіз статей, що містилися у газеті „Наука” та місяцословах, дозволяє простежити еволюцію народовецького руху й поступового його перетворення в українофільський. У згаданих виданнях виникли, а потім й збільшилися, передруки українських авторів, українських 
літературних творів. Починаючи від 1908 р. у місяцословах з'явилася постійна рубрика „3 української літератури” (Волошинъ 1907: 118), де публікувалися твори I. Франка, Т. Шевченка, С. Руданського, О. Маковея та інших письменників. Після появи цих творів починає змінюватися й мова закарпатських авторів - наближаючись до норм української літературної.

Таким чином до початку Першої світової війни в середовищі закарпатської інтелігенції сформувалися декілька національно-культурних рухів: русофільський, народовецький, який згодом перетворився в українофільський. Існував ще й угрофільський, але ми свідомо не братимемо його до уваги через його виразну тенденцію до мадяризації населення Закарпаття. Частина дослідників вважає, що угрофіли, борючись 3 русофілами, багато уваги приділяли фольклору та діалектам, стимулюючи тим самим формування народовецького руху. Проте, на нашу думку, перебільшенням $є$ вважати позитивний вплив угрофільського руху на становлення народовецького. Звернення угрофілів до закарпатських діалектів та фольклору розглядалося ними лише як засіб протистояння русофілам. У чехословацький період угрофільський рух злився з русофільським.

Фіксувати вплив русофільства чи народовецтва на свідомість усього населення дуже важко. Ми можемо використовувати лише думки інтелігенції, яка фіксувала симпатії мешканців цього регіону до того чи іншого національно-культурного руху. Такі свідчення важко назвати об'єктивними, адже часто власні переконання видавалися за підтримку мас. Ми можемо фіксувати політику Угорщини щодо населення Закарпаття. Найперше вона проявлялася у освітній сфері. Закон 1879 р. затвердив угорську мову як обов'язковий предмет навчання. Цей же закон визначав, що, починаючи з 1882 р., дипломи повинні були видавати лише тому, хто в достатній мірі володів угорською (Кобаль 2001б: 13-14). У 1907 р. міністр освіти Апоні провів шкільну реформу, ліквідувавши останні школи з руською (українською) мовою навчання і зменшивши кількість двомовних шкіл. Протягом 1907-1914 рр. кількість таких шкіл неухильно зменшувалася (Юревин 1930: 102), а на 1914 р. їх залишилося лише 34 (Неточаєв 1957: 114).

Перша світова війна прискорила процес формування національної свідомості населення. Коли мова заходить про ії̈ наслідки, як правило, 
наводиться статистика жертв та руйнувань, втрати воюючих сторін, спад економіки та рівня життя населення. Щоправда, війна мала й інший бік медалі, як не парадоксально це звучить, але вона сприятливо вплинула на процес консолідації народів Центральної Європи та Балкан. Зрештою, вона призвела до державотворчих процесів. Цей процес можна назвати „із війни у націю”, адже саме Перша світова війна стала каталізатором, який прискорив процес консолідації націй, зростання їхньої національної свідомості. Як правило, вплив позначався через посилення відчуття відмінності від представників інших народів, які воювали пліч-о-пліч, або були ворогами. Або посилення почуття єдності народів, які були розділені в межах Австро-Угорської та Російської імперій. Колишні селяни, а теперішні вояки австроугорської, німецької чи російської армій, гостро відчували свої національні особливості, створювали національні клуби та земляцтва, охочіше сприймаючи ідею національної державності.

Зрештою інтелігенція також усе більше цікавилася Україною. У місяцеслові за 1919 р. є цікава стаття, у якій, описуючи події на фронті в 1917 р. та укладання Брест-Литовського миру, автор пише:

Україна в давніх часах була самостійною, в 1654 році по договору переяславському Росія і Україна стали союзними державами, але коли в 1709 р. Петро Великий... в полтавській битві переміг гетьмана України Мазепу, тоді Україна підпала Росії. Однак жителі України, т.б. русини, не стали москалями, але зберегли свій малоруський язик і звичай (Война 1918: 2).

Та частина інтелігенції, яка стояла на народовецьких позиціях, намагалася з'ясувати чи зможе Закарпаття об'єднатися 3 іншими українськими землями після завершення війни. 3 цією метою А. Штефан, один з відомих діячів-народовців, їздив у Відень, де зустрічався з українськими представниками в австрійському парламенті (Штефан 1973: 35).

Зміни в національній свідомості далися взнаки одразу ж після закінчення війни. 3 розпадом імперії й кризою влади починають виникати Народні Ради. Вони, висловлюючи прагнення населення, приймають рішення про злуку з Україною. Угорський уряд, щоб зберегти під своїм контролем ці території, пішов на деякі поступки: було проголошено „Закон №10 про Руську Країну”, який давав краю 
певні автономні права. 10 грудня 1918 р. уряд скликав делегатів від Закарпаття для обговорення цього законопроекту. Однак, якщо представники інтелігенції висловлювалися дуже помірковано, то делегати від селян були налаштовані рішуче проти будь-якого союзу з Угорщиною. Збори відхилили угорський законопроект і постановили скликати загальні збори в Хусті, які мали визначити майбутнє Угорської Русі.

Збори, що мали репрезентувати все населення Угорської Русі, відбулися в Хусті 21 січня 1919 р. Вони прийняли рішення про об'єднання історичного Закарпаття з Соборною Україною (Стерчо 1965: 224).

Хоча дехто $з$ дослідників висловлює сумнів у тому, що Хустський Конгрес представляв усе населення історичного Закарпаття (Болдижар 1993: 159), однак 4 із 5 Народних Рад, які діяли на теренах Закарпаття: 2 листопада 1918 р. Хустська Руська Народна Рада, 8 грудня 1918 р. Свалявська Руська Народна Рада, 18 грудня 1918 р. Народна Рада в Сиготі, 8 листопада 1918 р. Руська Народна Рада в Старій Любовні (Пряшівщина) прийняли рішення про злуку з Україною (Химинець 1998: 306). Вірною Угорщині залишилася лише Ужгородська Рада. В силу міжнародних обставин рішення про приєднання Закарпаття до України не було втілено в життя. Хорошою альтернативою виявилося рішення приєднатися до новоствореної Чехословацької республіки, яка до того ж обіцяла надання широкої автономії. Обов'язок надання автономії був зафіксований у міжнародних договорах. Приєднання до Чехословаччини було настільки епохальним явищем, що усі відомі діячі та історики того періоду використовують термін „переворот”. В цей період відбуваються зміни й в національно-культурних рухах. Народовецький рух перетворюється на українофільський, а угрофільський рух зливається з русофільським. Пол Роберт Магочій вважає, що існували три альтернативи: русофільство, українофільство та консолідація населення Закарпаття як окремого народу (русинофільство) (Магочій 1994). Нам видаються такі висновки не обгрунтованими. Досліджуючи національно-культурні рухи другої половини XIX початку $\mathrm{XX}$ ст., ми можемо чітко визначити русофільський та народовецький рух, останній згодом переріс в українофільський, але не в стані зафіксувати руху в середовищі інтелігенції та населення, (який би) щоби визначав місцеве населення як окрему націю. 
„Таким чином”, русофільський рух в історичному Закарпатті формується у 1864 р. Культурно-просвітницьке „Общество святого Василія Великого" стає його організаційною основою. Загалом, вплив цього товариства на культурне життя народу був незначним, однак його діяльність мала величезне значення для подальшої історії і значний вплив на інтелігенцію. Певний час воно відігравало позитивну роль - протистояло мадяризації. Проте, пишучи „язичієм”, яке мало хто розумів, діячі „Общества” створили літературу для вузького кола людей, у той час як просвітницькою роботою для народу практично не займалися. Така діяльність товариства створила міф про „споконвічні” традиції „русскости”. Пізніше, у 20-30-х рр. ХХ ст., місцеві русофіли у полеміці з українофілами, доводячи свою правоту, часто посилалися на діяльність саме цього товариства. Русофільство „Общества святого Василія Великого” спричинило розкол у середовищі закарпатської інтелігенції. Частина останньої відмовилася від русофільства й створила народовецький рух.

Говорити про наявність українофільського руху в Закарпатті часів другої половини XIX ст. ми не можемо. Народовецький рух, який постав на противагу русофільству, був попередником українофільського. Загалом він пройшов тривалу еволюцію, поступово формуючи проукраїнські позиції: спочатку в середовищі інтелігенції, згодом й у населення.

\section{Література}

Война. Мъсяиослов на 1919 обыкновенный годъ имьющій дней 365, 1918, Мишанича О., Чучки П. (упоряд.), отъ имени „Акційнаго товариства УНІО” Августинъ Волошинъ. Годъ изданія 51-ый. - Унгваръ, с. 29-40.

Бірчак В., 1937, Литературні стремління Підкариатскоі Руси, Ужгород.

Болдижар М.М., 1993, Закарпаття між двома світовими війнами, Ужгород.

Волошинъ А. (упоряд.), 1907, Мъсяиослов на 1908 высокосный годъ, имъющій дней 366, т. 40, Унгваръ.

Волошин А., 1995, Спомини. Твори, Ужгород, с. 55-89.

Воскресенский Н.С., 1958а, Начало журналистики на Закарпатье, т. 23, Наукові записки, упоряд. С.П. Бевзенко, П.В. Лінтур, П.М. Лісовий, М.М. Плвсецький, П.П. Пономарьов, Г.А. Шелюто, Ужгород, с. 5-25.

Воскресенский Н.С., 1958b, Художественная литература на страницах Закарпатской газеты ,,Свет”, т. 6, Научные записки, упоряд. Н.С. Антошин, С.Ф. Бевзенко, Н.С. Воскресенский, П.П. Пономарев, Ужгород, с. 125-148. 
Гаджега Ю., 1925, Исторія общества св. Василья Великаго и речъ ко дню 60-льтія его учреждения, Ужгородъ.

Голенда Й., 1984, Анатолій Кралицький. Розвідка і вибрані твори, Братислава.

Недзьльскій Е., 1932, Очеркъ карпаторусской литературы, Ужгородъ.

Державний архів Закарпатської області. Фонд (ДАЗО), 72, опис 2, справа 107. Реферат А. Волошина на з’їзді товариства «Просвіта» в Ужгороді [нерозповсюджений твір, без вказаного місця видання].

Данилюк Д., 1997, Історія Закарпаття в біографіях і портретах, Ужгород.

Кобаль Й.В. (упоряд.), 2001a, Донесення єпископа Стефана Панковича міністру у справах культу й освіти 8 вересня 1873 р., До історії начіональних меншин Австро-Угорщини (XIX-поч. XX cm.), Ужгород, с. 16-17.

Кобаль Й.В., (упоряд.), 2001б, Закон число 1879, том ХVIII. Про навчання угорської мови у закладах народної освіти. До історії національних меншин Австро-Угорщини (ХIX-поч. XX ст.), Ужгород, с. 13-14.

Кобаль Й.В., (упоряд.), 2001в, I ми в Європі: Протест галицьких русинів против мадярського тисячоліття. До історії начіональних меншин АвстроУгорщини (XIX-поч. XX cm. ), Ужгород, с. 18-27.

Коломиец И.Г., 1962, Социально-економические отношения и общественное движение в Закарпатье во второй половине XIX столетия, т. 2, Томск.

Кондратович М., 1927, Коротка исторія Общества св. Василія Великого. М. Кондратович, Ювілейный илюстрованый календар на переступный рок 1928. Рок выдання 60-ый, Ужгород, с. 41-48.

Лісовий П., 1970, Українська література в закарпатській періодиці (кінец̧ь XIXпочаток XX cm.), „Радянське літературознавство” № 10, с. 34-40.

Магочій П.Р., 1994, Галичина. Історичні есе, Львів.

Мазурок О., 2001, Юрій Жаткович як історик та етнограф, Ужгород.

Мыцюк О., 1930, Приятель „,пораненого брата”. М.П. Драгоманів (B 35-ту річниию смерти), „Р. Подкарпатска”, т. 6, Ужгород, с. 152-155.

Микитась В., 1977, 3 ночі пробивалися, Ужгород.

Милославскій П., 1936, Хоровое пьніе на Подкарпатской Руси. П. Милославскій, Подкарпатская Русь за годы 1919-1936, Ужгородъ, с. 125-130.

Мушинка М., 1987, Володимир Гнатюк - життя та його діяльність в галузі фольклористики, літературознавства та мовознавства, Записки наукового товариства ім. Шевченка: праці філологічної секції, т. 207, Париж-НьюЙорк-Сідней-Торонто.

Нарьчія околицы Рахова (Марам.). Переведено изъ брошюры Александра Бонкалова, профессора гимназіи дьендьешской // Наука, 1911, с. 6.

Недзъльскій Е., 1932, Очеркъ карпаторусской литературы, Ужгород, с. 290.

Неточаєв В., 1957, Закарпаття напередодні першої світової війни (1908-1914) // Наукові записки, т. 29, упоряд. В.І. Неточаєв et al., Ужгород, с. 94-137.

Общество СВ. Василія Великого, 1866 // Мъсяиослов на 1867 годъ. Изданъ обществомъ СВ. Василія В, Ужгородъ, с. 69-70.

Пекар В. (о. Анастасій), 1991, Стосунки Володимира Гнатюка з закарпатським 
істориком Ю.Жатковичем // Матеріали міжнародної наукової конферениії „від наукового товариства ім. Шевченка до Українського вільного університету”. Пряшів-Свидник, 12-15 червня 1991, Київ-Львів-Пряшів-МюнхенПариж-Нью-Йорк-Торонто-Сідней, с. 58-70.

Протоколь перваго засъданія комитета Общества св. Василія В. происходившаго въ Ужгородъ 20 окт. (1 ноябр.) 1866, 1866 // Мъсяцослов на 1867 годъ, c. 76-81.

Протоколь Перваго общаго собранія Общества. св. Василія В. // Мъсяияослов на 1867 годъ, 1866, Ужгородъ, с. 70-75.

Протоколь третяго засьданія комитета О. св. Василія В. происходившаго въ Унгварь 15 (27) Декабря 1866, 1867 // Мъсяџослов на 1868 годъ, Ужгородъ, c. $79-85$.

Сильвай И.А., 1957, (Уриил Метеор), Избраннье произведения, Ужгород.

Стерчо П., 1965, Карпато-украӥнська держава: До історії визвольної боротьби карпатських українців у 1919-1939 роках, Торонто.

Стряпко I., 2012, Товариство „Просвіта” в громадсько-політичному та культурному житті Закарпаття (1920-1939), Ужгород.

Тіхий Ф., 1996, Розвиток сучасної літературної мови на Підкарпатській Русі, перекл. Л. Белей, М. Сюсько, Ужгород.

Феделеш К., 1914, Руській народъ, 5, Наука, Львів, с. 21-24.

Ференц П., 2005, Етнонаціональна орієнтація украӥнців Закарпаття в 20-30-ті роки ХХ століття, Мукачево.

Ференц П., 2001 Вплив культурних факторів на зростання української національної свідомості украӥниів Закарпаття другої половини ХІХ першої половини $X X / /$ „Карпатика” 12, Ужгород, с. 250-264.

Франко I., 1900, Карпаторуська література XVII-XVIII віків // Записки наукового товариства імени Шевченка виходять у Львові щзодва місяці під редакиією Михайла Грушевського, т. 38.

Химинець Ю., 1998, Тернистий шлях до України, упорядник М. Химинець, Ужгород.

Хланта М., 1993, Значення наукової діяльності Гнатюка у формуванні украӥнської мовної свідомості на Закарпатті // Українська мова на Закарпатті у минулому і сьогодні, Ужгород, с. 321-325.

Чучка Ю. (упоряд.), 1899, Наша книгопечатня // Мъсяџослов на 1900 годъ, им ъюшій дней 366, т. 32, Унгваръ, с. 40-46.

Шандор В., 2000, Спомини, т. 1, Карпатська Украӥна 1938-1939, Ужгород.

Штефан А., 1973, За правду і волю: Спомини і дещзо з історії Карпатської України, Торонто.

Юревин Т. 1930, Наше руське школльництвво в десятоิм роияо самостойиости ЧСР, ,Учитель” № 3-4, с. 94-103. 


\section{Rezijanščina: geneolingvistična in sociolingvistična opredelitev}

AвSTRACT: Šekli Matej, Rezijanščina: geneolingvistična in sociolingvistična opredelitev (Resian: Genealogical and Sociolinguistic Definition). „Poznańskie Studia Slawistyczne” 8. Poznań 2015. Publishing House of the Poznan Society for the Advancement of the Arts and Sciences, pp. 199214. ISSN 2084-3011.

The article presents a genealogical and sociolinguistic classification of Slavic idioms, drawing on the example of Resian. Resian is an autochthonous idiom, spoken in the Resia Valley (Ital. Val Resia), which belongs to the Municipality of Resia (Rozajanski kumün, Ital. Comune di Resia) within the Province of Udine (Ital. Provincia di Udine) in Friuli-Venezia Giulia, an autonomous Italian region. The genealogical linguistics studies the genealogical relationship between idioms and on the basis of the nature of their mutual relationship establishes their genealogical classification. In this respect, Resian must be viewed as a dialect of Slovene. Sociolinguistics, on the other hand, tends to view languages as systems of communication and on the basis of different spheres of usage assigns their sociolinguistic classification. From the latter viewpoint, Resian can be defined as a literary/standard microlanguage within Slovene, which due to the absence of the Slovene standard language is put into the role of the local literary language with a rather limited scope of functional varieties.

KEYwords: genealogical classification; sociolinguistic classification; Slavic languages; Slavic literary/standard languages; Slavic literary/standard microlanguages; Resian dialect of Slovene; Rezijansko dialect; Resian literary/standard microlanguage

\section{Jezikoslovne klasifikacije idiomov}

Jezikoslovje (lingvistika) preučuje različne pojavnosti naravnega človeškega jezika ter se glede na zorni kot pogleda nanj deli na tri temeljne veje. To so geneolingvistika (genetsko jezikoslovje), ki preučuje genetska, tj. sorodstvena razmerja med idiomi, tipolingvistika (tipološko jezikoslovje), ki preučuje zgradbo nekega idioma, in sociolingvistika (družbenostno jezikoslovje), ki jezik preučuje kot sporazumevalni sistem kolektiva ali 